\title{
Darkness and Light in Black and White: Travelling Mission Imagery from the New Hebrides
}

\section{Lamont Lindstrom}

'Missi! come quick!' the caption reads, 'Miaki's men are stealing your sheets and blankets!' (Figure 7). ${ }^{1}$ The 'missi' was John Gibson Paton. The thieves were men and boys from Port Resolution, Tanna, in what was then the southern New Hebrides (Vanuatu today). The caption comes from one of many hagiographic accounts of Paton's missionary exploits on that island between 1858 and $1862 .^{2}$ Paton's pilfered bed linen became a popular part of his storied travails, told and retold in several dozen books for children and adults that sprang from his own multi-volume autobiography. ${ }^{3}$ Although this account offered no illustrations except for a dignified frontispiece portrait of the man himself, most subsequent versions of the story featured numerous photographs and line drawings. Illustrations of that crime

1 Bessie L. Bryum, 1924, John G. Paton: Hero of the South Seas, Anderson, IN: Warner Press, p. 34. Images discussed in this chapter are all now in the public domain.

2 Ron Adams provides a more tempered history of Paton's endeavours. See Ron Adams, 1984, In the Land of Strangers: A Century of European Contact with Tanna, 1774-1874, Pacific Research Monograph. Canberra: Australian National University Press.

3 John G. Paton, 1890, An Autobiography, London: Hodder and Stoughton; A.K. Langridge and F.H.L. Paton, 1910, John G. Paton: Later Years and Farewell, London: Hodder and Stoughton. 
scene appear in other editions of Bessie Byrum's Paton bio, although they vary somewhat, and depictions of the stolen sheets and blankets likewise embellish several other Paton biographies (Figure 8). ${ }^{4}$

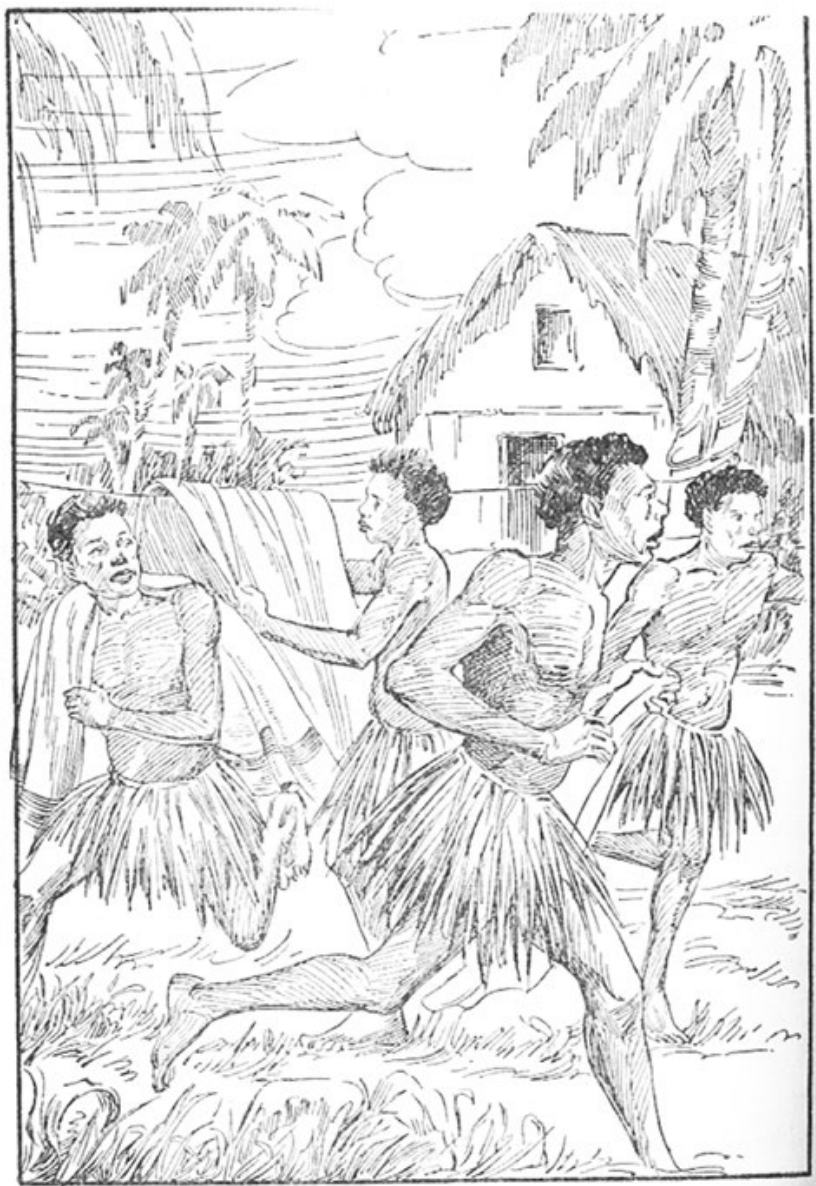

"Missi! come quick! Miaki's men are stealing your sheets and blankets!"

Figure 7. Stealing sheets and blankets!

Source. Bessie L. Byrum, 1924, John G. Paton: Hero of the South Seads, Anderson, IN: Warner Press, p. 24.

4 See, for example, John Paton, 1898, The Story of John G. Paton Told for Young Folks, or Thirty Years among South Sea Cannibals, London: Hodder and Stoughton, p. 89; John Paton, 1923, The Story of John G. Paton's Thirty Years with South Sea Cannibals, ed. Dr. James Paton, revised by A.K. Langridge, London: Hodder and Stoughton, p. 44; see also Charles D. Michael, 1912, John Gibson Paton, DD: The Missionary Hero of the New Hebrides, London: S.W. Partridge \& Co., p. 43. 


\section{DARKNESS AND LIGHT IN BLACK AND WHITE}

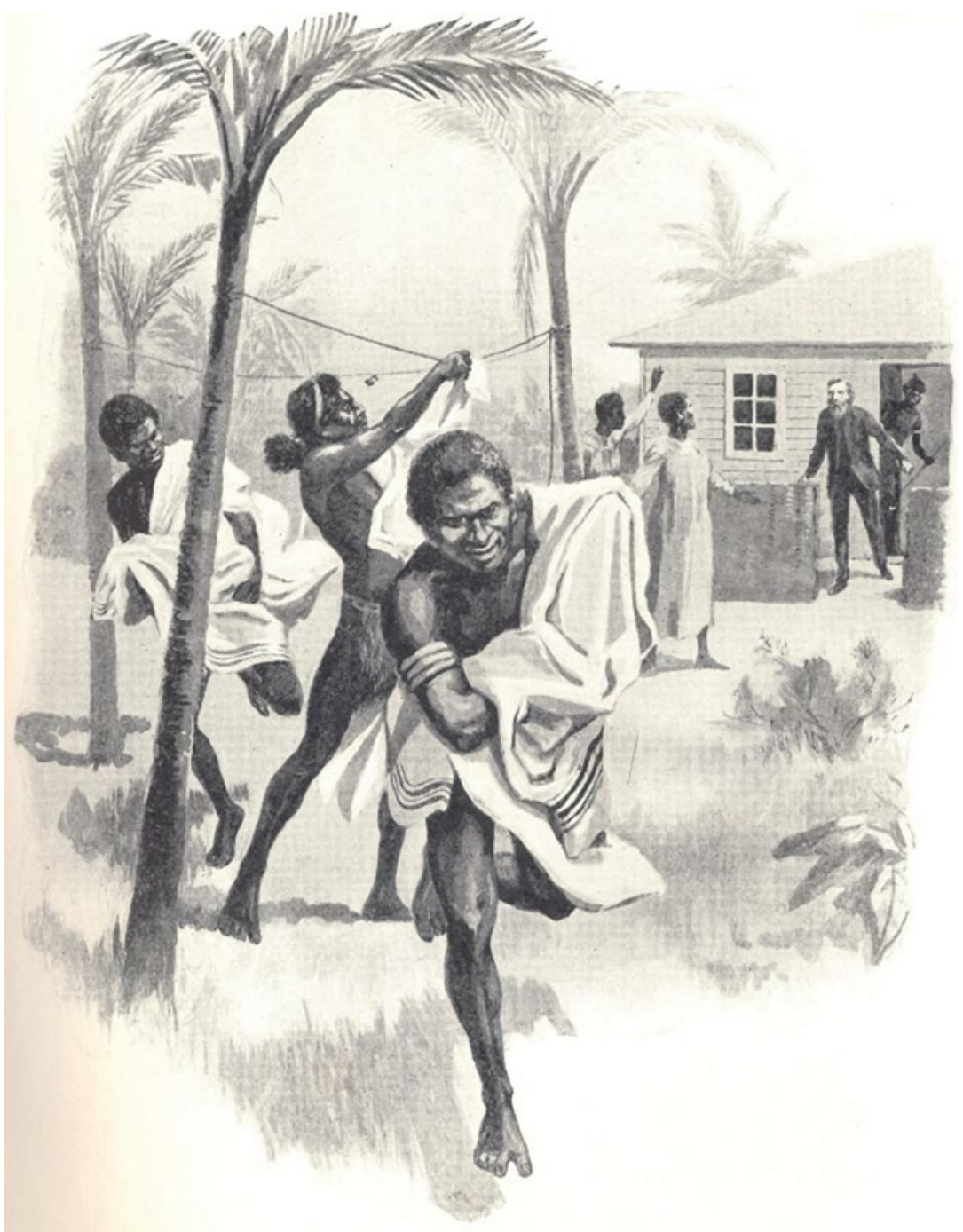

STEALING THE BEDCLOTHES.

Figure 8. Stealing the bedclothes.

Source. John Paton, 1923, The Story of Dr. John G. Paton's Thirty Years with South Sea Cannibals, London: Hodder and Stoughton, p. 45. 
In the years before mass tourism, mission imagery helped shape metropolitan understanding of island life. ${ }^{5}$ Mission imagery, whose heyday lasted from the 1880s through the 1930s, swamped the world market for views of the southwest Pacific, and particularly of the New Hebrides. ${ }^{6}$ It dominated global circuits, shaping ways in which island life was 'pictured' and understood, until the outbreak of the Pacific War during which Vanuatu's principal airport was constructed and the subsequent development of mass tourism carried by plane and cruise ship, ${ }^{7}$ most of these tourists arriving with their own cameras in hand. Before the Pacific War, however, Presbyterian missionaries in the New Hebrides and their supporters, during the late nineteenth and early twentieth centuries, generated a notable archive of island images illustrating their autobiographies and other accounts. They also produced illustrated mission periodicals, picture postcards, magic lantern slides, and even lapel pins (Figure 9). To help circulate their published and more ephemeral imagery, island-based missionaries regularly toured Australia, New Zealand, Scotland and North America to lecture, raise funds, and sell miscellaneous depictions of their labours to homeland congregations who thereby vicariously came to know South Pacific people and places. ${ }^{8}$ The mission graphic archive is substantial and one can only sample it here to explore both the types of pictures it circulated and the views these portrayed.

5 Nicholas Thomas, 1992, 'Colonial conversations: Difference, hierarchy, and history in early twentieth-century evangelical propaganda', Comparative Studies in Society and History 34: 366-89, p. 371; Christine Weir, 2013, “'Deeply interested in these children whom you have not seen": The Protestant Sunday School view of the Pacific', Journal of Pacific History 48: 43-62. The illustrators and photographers who produced these images were often anonymous, typically unacknowledged or only quickly identified by signature or initials, for example J.F. and W. Hatterell in Michael, John Gibson Paton, DD; and James Finnemore in John Paton, 1898, The Story of John G. Paton Told for Young Folks, or Thirty Years among South Sea Cannibals, London: Hodder and Stoughton.

6 Weir, "'Deeply interested in these children whom you have not seen"', pp. 61-62.

7 Ngaire Douglas, 1996, They Came for Savages: 100 Years of Tourism in Melanesia, Alstonville, NSW: Southern Cross University Press.

8 For an analysis of two Presbyterian photo albums now in church archives in Dunedin, see Antje Lübcke, 2012, 'Two New Hebrides Mission photograph albums: An object-story of storyobjects', Journal of Pacific History 47: 187-209. 


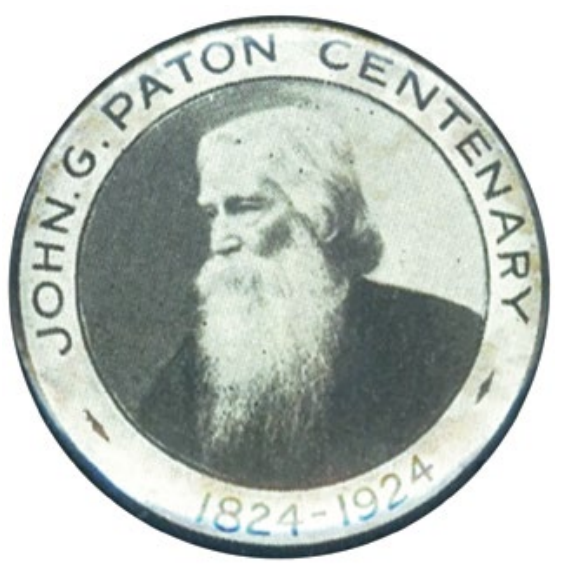

Figure 9. John G. Paton lapel pin.

Source. A.W. Patrick (manufacturer), Fitzroy, Vic, 1924; author's collection.

\section{Pictures}

Until the 1860s, relatively few images of New Hebridean life and landscape had circulated abroad; these mostly prints by William Hodges who sailed as an artist on James Cook's second voyage, other illustrated voyage accounts, and scattered encyclopedic illustrations. Beginning in the 1860s, a flush of illustrated mission texts began to depict new stories of the archipelago - two of the first being George Patterson's Memoirs of the Rev. S. F. Johnston, the Rev. J. W. Matheson, and Mrs. Mary Johnston Matheson, Missionaries on Tanna (1864) and his Missionary Life among the Cannibals: Being the Life of the Rev. John Geddie, D.D., First Missionary to the New Hebrides (1882). ${ }^{9}$

Missionary writing then dominated popular literature about the southern and central New Hebrides, and associated pictures, postcards and lantern slides also travelled widely. Collector John Ferguson compiled a three-part bibliography of Presbyterian literature printed for diverse audiences that ran to 135 pages. ${ }^{10}$ While missionary

9 George Patterson, 1864, Memoirs of the Rev. S. F. Johnston, the Rev. J. W. Matheson, and Mrs. Mary Johnston Matheson, Missionaries on Tanna, Philadelphia: W.S. \& A. Martien; and George Patterson, 1882, Missionary Life among the Cannibals: Being the Life of the Rev. John Geddie, D.D., First Missionary to the New Hebrides, Toronto: James Cample \& Son, James Bain \& Son, and Hart \& Co. This literature had a longer history in Polynesia; missionaries landed in Tahiti in the 1790s, Tonga and Hawaii in the 1820s, and Samoa in the 1830s.

10 John Alexander Ferguson, 1917-1943, A Bibliography of the New Hebrides and a History of the Mission Press, parts 1-3, Sydney: privately printed. 
representations of the New Hebrides competed with other imagery offered by Royal Naval officers, administrative memoirists, occasional freelance journalists and writers like Beatrice Grimshaw, ${ }^{11}$ Jack and Charmian London, passing professional photographers like J.W. Beattie and Martin and Osa Johnson, ${ }^{12}$ and various early anthropologists including W.H.R. Rivers, R.H. Codrington, Felix Speiser, Bernard Deacon, John Layard, T.T. Barnard, and Clarence Humphreys, the journalists, photographers, and anthropologists who visited the islands themselves typically travelled along mission circuits. ${ }^{13}$ Beattie, for example, sailed on the Melanesian Mission's Southern Cross and the Johnsons depended on the hospitality of Catholic priest Jean-Baptiste Prin on Vao. ${ }^{14}$

The Presbyterians circulated their island imagery in a variety of media and formats including books (missionary memoirs, accounts, and biography) and illustrated periodicals. These latter included Quarterly Jottings from the New Hebrides (which, published by the John G. Paton fund, ran from 1863 through 1966), New Hebrides Mission Reports, New Hebrides Magazine, The Record: The Sabbath School and Missionary Magazine of the Presbyterian Church of Australia, and Our Missionaries at Work. Presbyterian exploits were also selectively featured in The New Zealand Missionary Record, The Outlook, Break of Day, Canada's The Presbyterian Record, and also in several Scottish Presbyterian church journals. These publications featured both photographs and line drawings, some of the latter made from original photographs were more expensive to reproduce. As reproductive technology developed and rotogravure supplanted lithography, missionary texts were more abundantly illustrated. ${ }^{15}$ Alongside these

11 Eugénie Laracy and Hugh Laracy, 1977, 'Beatrice Grimshaw: Pride and prejudice in Papua', Journal of Pacific History 12: 154-75; Douglas, They Came for Savages, p. 65.

12 Prue Ahrens, Lamont Lindstrom and Fiona Paisley, 2013, Across the World with the Johnsons: Film, Photography, and American Empire, Farnham: Ashgate.

13 For a summary of available pre-World War II travel literature that touched on Vanuatu, see Douglas, They Came for Savages, pp. 40-48. Burns Philp in 1903 did begin bringing intrepid tourists into the islands who shipped on that company's cargo steamers. To attract custom, in 1911 it began publishing a handbook, Picturesque Travel, later replaced by The BP Magazine. See Douglas, They Came for Savages, pp. 54-56.

14 The Johnson's 1918 silent features Among the Cannibal Isles of the South Pacific and Cannibals of the South Seas, with associated shorts, introduced New Hebrides people and places to early movie fans.

15 Illustrations in earlier volumes, reproduced more expensively, were often of higher quality. See, for example, the engravings in Patterson, Missionary Life Among the Cannibals, 1882. 
publications, mission images also circulated as magic lantern slides and picture postcards - the same image often deployed in several different media as book illustration, magic lantern slide and postcard.

Missionaries on home leave typically lectured to church congregations, beating the bushes for cash donations and other forms of support. They captivated audiences with magic lantern slides depicting heroic lives and gripping examples of danger and salvation. Back in the field, beginning in the 1880s, they also deployed different limelighted slide sets illustrating the life of Jesus and other Biblical figures. ${ }^{16}$ Tanna mission wife Agnes Watt, for example, reported that on 26 March 1885, 'In the evening, we had a Magic Lantern display to a crowded house, people have come miles to see it. The pictures were explained, and in that way we hope some heard the gospel who would not attend a service either in church or the open air. ${ }^{17}$ And, John Paton's missionary son Frank on east Tanna similarly reported that:

A never-ending delight to the natives was our magic lantern. We were so thankful to get a box of beautiful Scripture slides from London. The picture that always made the deepest impression upon the natives was that of the Crucifixion. Even determined Heathen came to see the wonderful pictures which could only be seen in the dark $!^{18}$

If pictures of baby and crucified Jesus delighted on Tanna, missionaries when on leave instead lit up their lectures with pictures of savage heathen and cannibal killers. Few of these slides survive today, but examples that do (many once marketed by Australian photographers Henry King and John W. Lindt) depict various groupings of villagers and suggest the flavour of these presentations. A King lantern slide innocuously labelled 'Erromanga New Hebrides' (Figure 10) had appeared earlier in at least two mission books. Maggie Paton in 1894

16 For missionary uses of the magic lantern elsewhere, see Daile Kaplan, 1984, 'Enlightened women in darkened lands', Studies in Visual Communication 10: 61-77; Elizabeth Shepard, 1987, 'The magic lantern slide in entertainment and education, 1860-1920', History of Photography 11: 91-108; and Paul Landau, 1994, 'The illumination of Christ in the Kalahari Desert', Representations 45: 26-40. The Anglicans, in The Southern Cross Log, published a guide for successful meetings including how to stage a magic lantern show. Pointers included 'The best Lantern obtainable and an experienced operator having been secured', and 'Let a Collection be taken during a hymn in the middle of the address'. See Melanesian Mission, 1913, 'What helps to make successful meetings: Hints to Local secretaries', The Southern Cross Log (December): 197-99.

17 Agnes Craig Patterson Watt, 1896, Twenty-five Years' Mission life on Tanna, New Hebrides, Paisley: J. and R. Parlane, p. 242.

18 Frank H.L. Paton, 1903, Lomai of Lenakel: A Hero of the New Hebrides. A Fresh Chapter in the Triumph of the Gospel, London: Hodder and Stoughton, p. 152; at another lantern show Paton reported that 'Jesus as a Baby' also 'impressed them most'. Paton, Lomai of Lenakel, p. 165. 
captioned this 'The Murderer of [missionary George] Gordon, and His Child' (attributing the photograph to fellow missionary William Gunn). ${ }^{19}$ H.A. Robertson also used the same photograph in his own New Hebrides book, but his caption named the murderer: 'Uhuvili and His Child. ${ }^{20}$

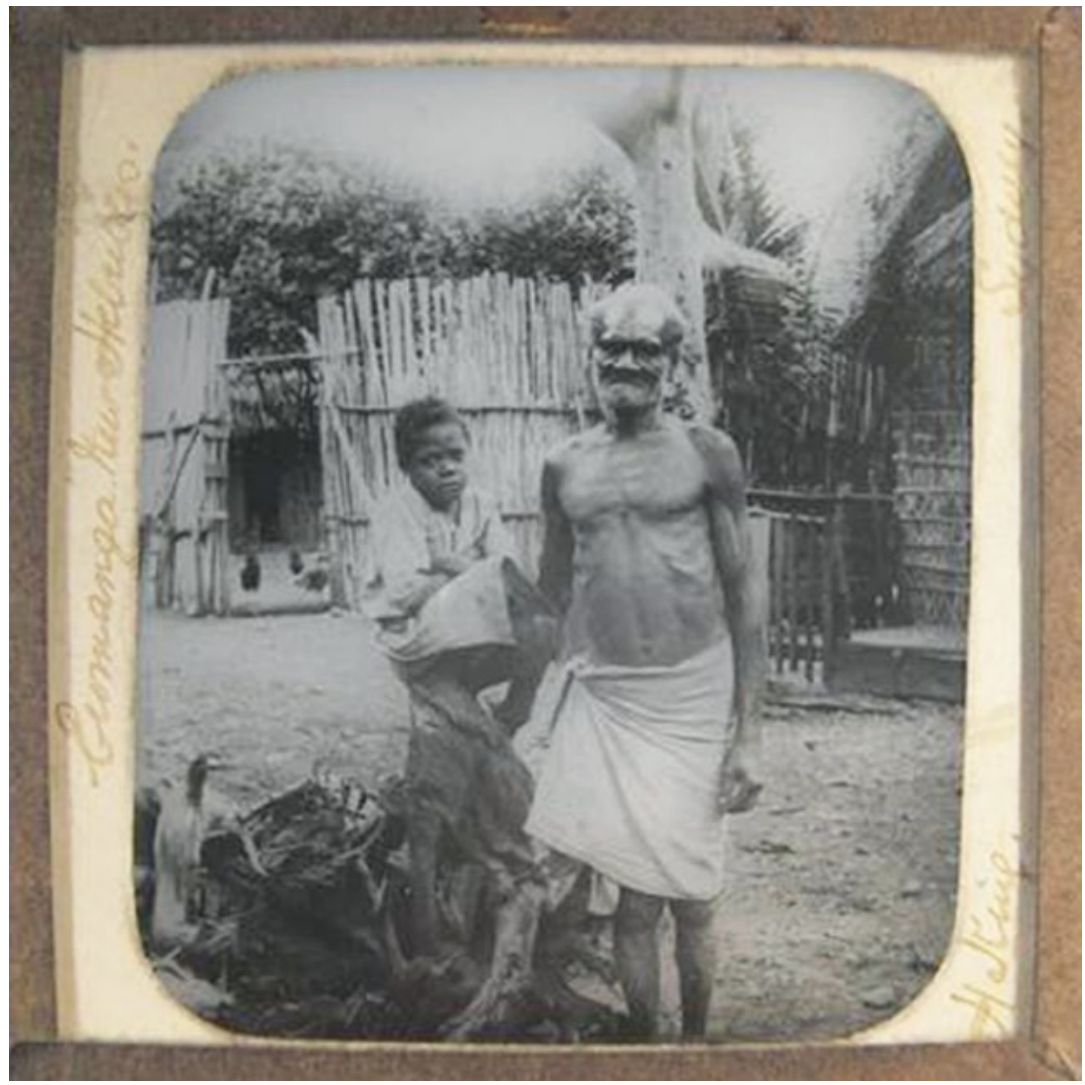

Figure 10. Magic lantern slide, Erromanga New Hebrides (Uhuvili and his child).

Source. Henry King (photography studio), Sydney; author's collection.

King, Lindt, Beattie and other photographers who converted mission negatives into lantern slides also sold postcards. Beattie churned out 800 New Hebrides postcards reproduced from photographs he shot

19 Maggie Whitecross Paton, 1894, Letters and Sketches from the New Hebrides, London: Hodder and Stoughton, p. 126.

20 H.A. Robertson, 1903, Erromanga: The Martyr Isle, London: Hodder and Stroughton, facing p. 74 . 
during his 1906 visit to the archipelago, ${ }^{21}$ and missionaries themselves went into the postcard business. ${ }^{22}$ A contemporary Melanesian Mission guide for staging successful magic lantern shows highlighted associated possibilities for card sales: 'Stands for post cards, as used on railway platforms can be easily borrowed. ${ }^{23}$ Like lantern slides, images first featured in missionary books also sold as postcards. 'The Miracle of Water from the Well', a drawing included in Michael, ${ }^{24}$ celebrated the divine assistance that guided Paton in digging for water on Aniwa, a small atoll that neighbours Tanna: 'It was the Missi's God, the mighty Jehovah, who had wrought this great and wonderful thing. ${ }^{25}$ This image also appeared as a coloured postcard (Figure 11) to be purchased and posted by Presbyterian supporters. ${ }^{26}$ Missionary texts featured these illustrations, missionaries displayed and sold them, while their supporters appreciated and circulated them further in church lending libraries and by post.

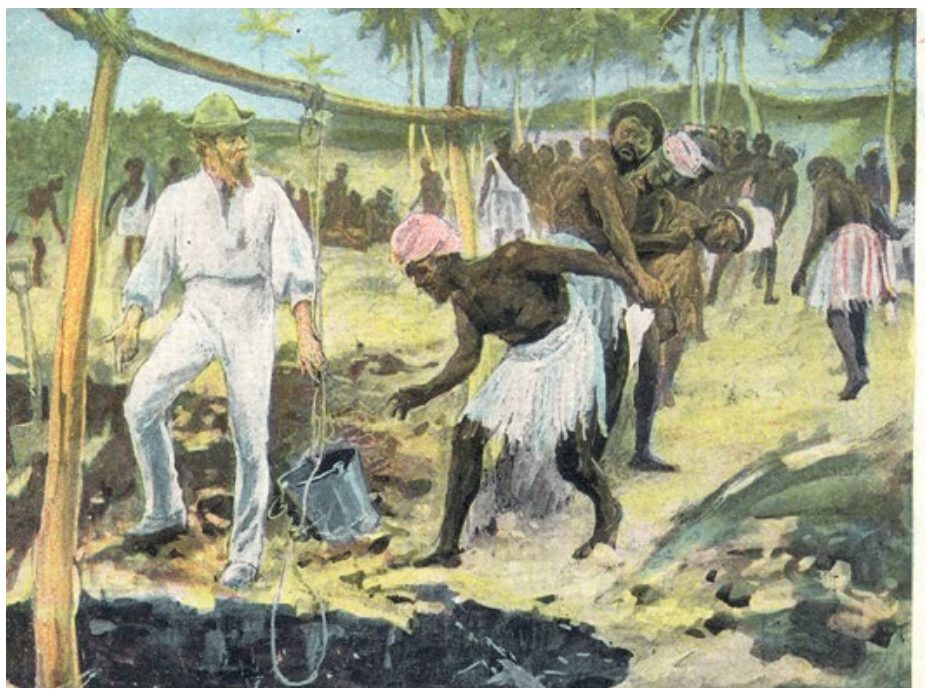

Figure 11. John Paton, as postcard.

Source. Anonymous, printed in Germany; author's collection.

21 Frédéric Angleviel and Max Shekleton, 1997, “'Olfala pija blong Niuhebridis blong bifo": Old pictures of the early New Hebrides (Vanuatu)', Pacific Studies 20: 161-85, p. 164.

22 Ibid., p. 169.

23 Melanesian Mission, 'What helps to make successful meetings', p. 197.

24 Michael, John Gibson Paton, DD, p. 131.

25 Ibid., p. 132.

26 Lübcke quotes missionary William Milne who wrote to a colleague that 'our photo is pretty good' when the celebratory postcard featuring his portrait had sold out. See Lübcke, 'Two New Hebrides Mission photograph albums', p. 193n22. 


\section{Portrayals}

Designed to cultivate support and to justify Presbyterian endeavour, missionary imagery illustrated the master story of savagery and its salvation. The chief trope was one of darkness and light, of Christian enlightenment. This was a hugely popular and long-standing Christian metaphor borrowed immediately from Biblical text (e.g. John 1:5) and missionaries deployed it everywhere, extravagantly and often. The Presbyterians in the New Hebrides shared appreciation of these same lights. They christened their various mission vessels Dayspring. They titled a jubilee history of the mission Light in Dark Isles ${ }^{27}$ and otherwise celebrated the light in book titles like Heralds of Dawn. ${ }^{28}$ Their books featured recurring graphics of white triumph over black. Colour contrast was both spiritual and racial and was further highlighted by missionary sartorial fondness for white garments (at least in book illustration, Figures 11 and 12). ${ }^{29}$ John Paton's white raiment signified his bright heart and soul - white skin, white trousers, white heart. Mission photos pointedly emphasised tonal contrasts. Maurice Frater, who ministered on Paama and Epi islands, 1900-1939, included in his autobiography one study in contrast, 'natives admiring photographs of themselves' ${ }^{\prime 30}$ wherein white suits juxtaposed dark nudity, and cummerbund reflected penis wrapper, in photograph and in life alike (Figure 13). When projected at night with a magic lantern, these images of white body and spirit were particularly powerful as they 'floated and shimmered' in the darkness. ${ }^{31}$

27 Alexander Don, 1918, Light in Dark Isles: A Jubilee Record and Study of the New Hebrides Mission of the Presbyterian Church of New Zealand, Dunedin: Foreign Missions Committee, Presbyterian Church of New Zealand.

28 William Gunn, 1924, Heralds of Dawn: Early Converts in the New Hebrides, London: Hodder and Stroughton.

29 Michael, John Gibson Paton, DD, p. 69.

30 Maurice Frater, 1922, Midst Volcanic Fires: An Account of Missionary Tours among the Volcanic Islands of the New Hebrides, London: James Clarke \& Co, facing p. 72.

31 Landau, 'The illumination of Christ in the Kalahari Desert', p. 32. 


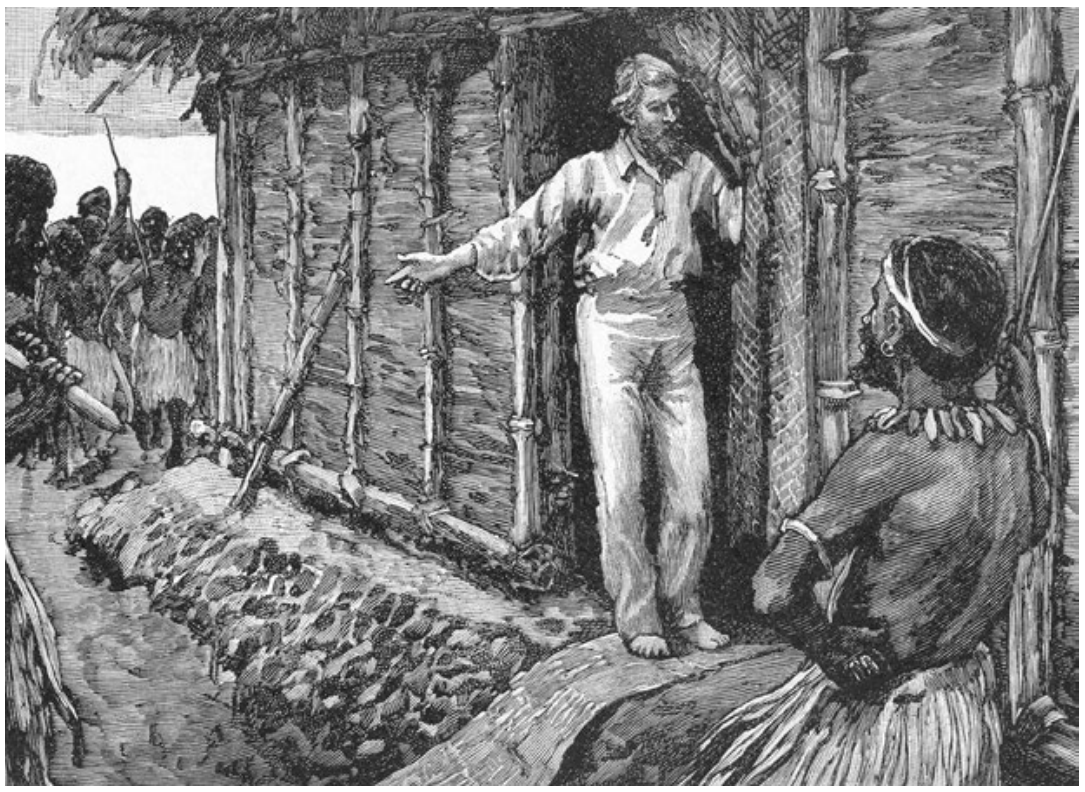

Figure 12. Paton in white.

Source. Charles D. Michael, 1912, John Gibson Paton, DD: The Missionary Hero of the New Hebrides, London: S.W. Partridge, p. 69.

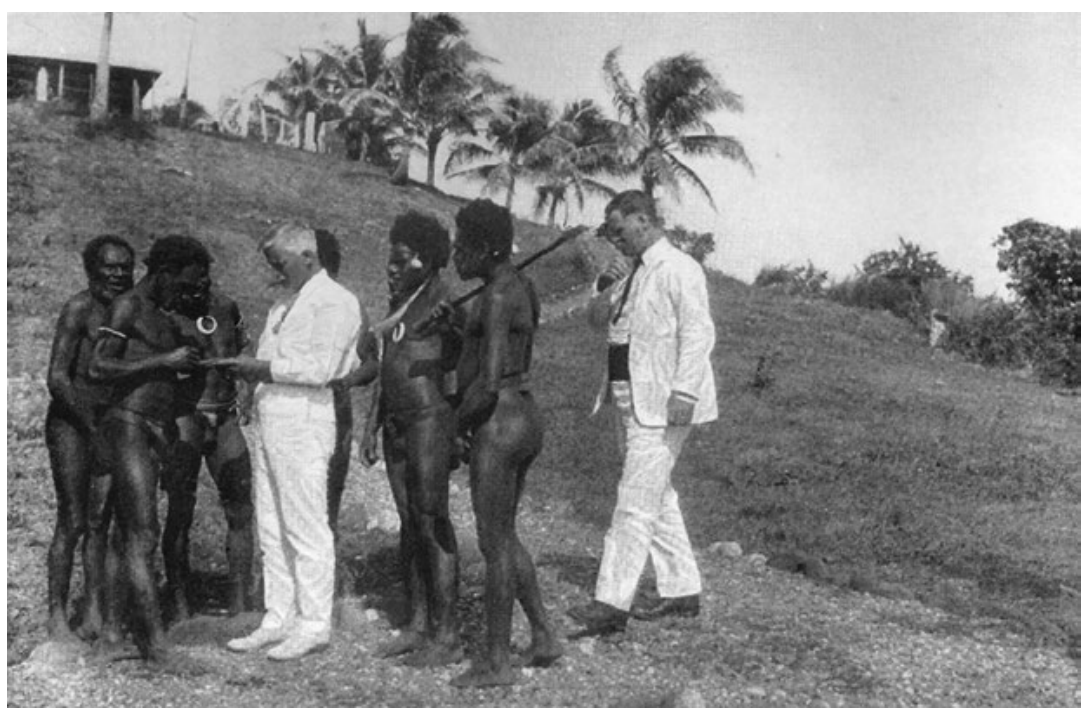

Figure 13. Light and dark.

Source. Maurice Frater, 1922, Midst Volcanic Fires: An Account of Missionary Tours among the Volcanic Islands of the New Hebrides, London: James Clarke, p. 73. 


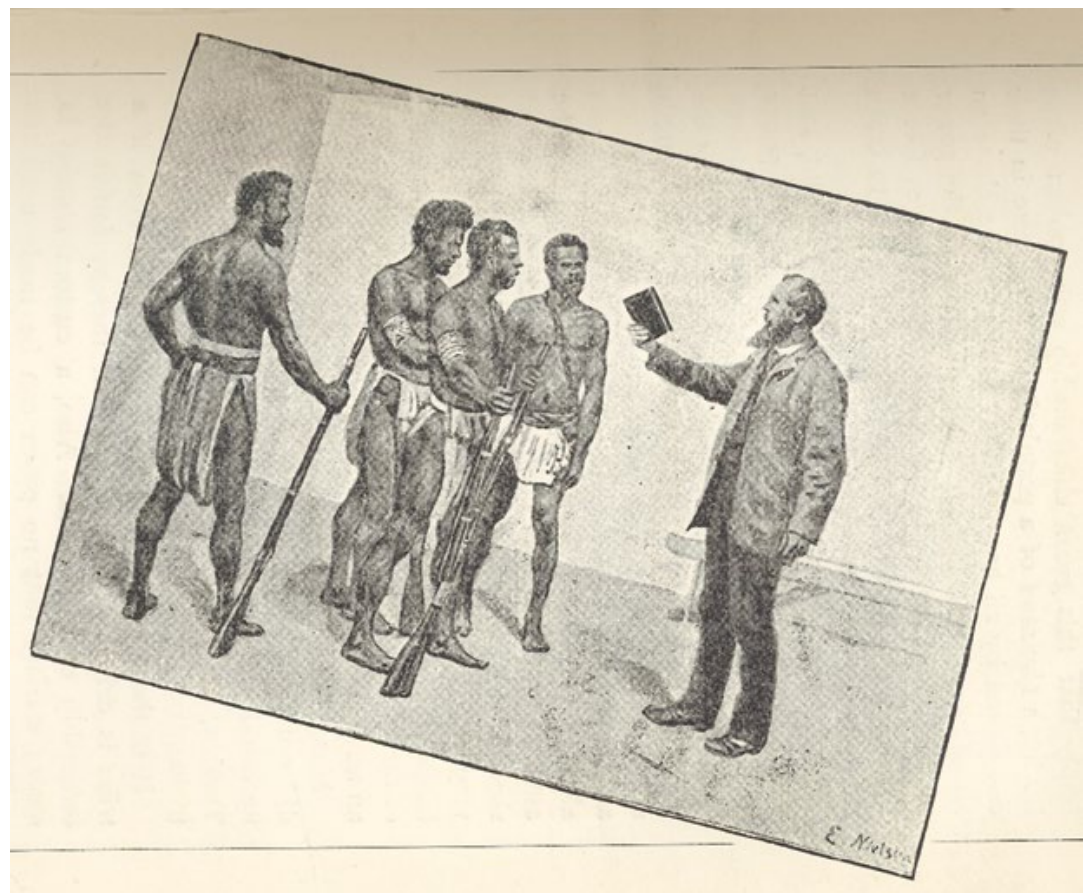

Figure 14. The missionary's 'gun'.

Source. Oscar Michelsen, 1893, Cannibals Won for Christ: A Story of Missionary Perils and Triumphs in Tongoa, New Hebrides, London: Morgan and Scott, p. 41.

Christian light must engulf heathen darkness in the end. Miaki's men on Tanna, after all, understandably desired and stole John Paton's white sheets and blankets. The Christian gospel vanquishes the darkness, the sacred pen mightier than the sword (or, rather, rifles and clubs in the New Hebrides). The Bible, in fact, was the missionary's 'gun' (Figures 14 and 15). ${ }^{32}$ Mission imagination was also notably fond of before/after comparison - this second sort of juxtaposition the intrinsic consequence of initial darkness/light contrast. Transformed and enlightened islanders would enwhiten, and mission publication regularly illustrated this process in 'before and after' views of village scenes (Figures 16 and 17). ${ }^{33}$ New churches and schools came to supplant old heathen structures, as another mission postcard (Figure 18) depicted - the school, here,

32 Oscar Michelsen, 1893, Cannibals Won for Christ: A Story of Missionary Perils and Triumphs in Tongoa, New Hebrides, London: Morgan and Scott, p. 41; Paton, The Story of John G. Paton Told for Young Folks, or Thirty Years among South Sea Cannibals, p. 81.

33 Emma H. Adams, 1890, Two Cannibal Archipelagoes: New Hebrides and Solomon Groups, Oakland, CA: Pacific Press Publishing Co., pp. 90-91. 
a key institution in Christian education and enlightenment. Mission images also celebrated transformations in native demeanour, including, notably, their now clothed, newly spruced up bodies. Futuna Island missionary William Gunn's attempt at one such comparative portrayal (Figure 19) was spoiled, somewhat, by his heathen subject's move to cover over her traditional bark skirt with a dress ('heathen to the left, dressed in order to have her photo taken'), ${ }^{34}$ although her wilder hair and bark underskirt contrast vividly with her Christian sister's long, white Mother Hubbard and elegant turban.

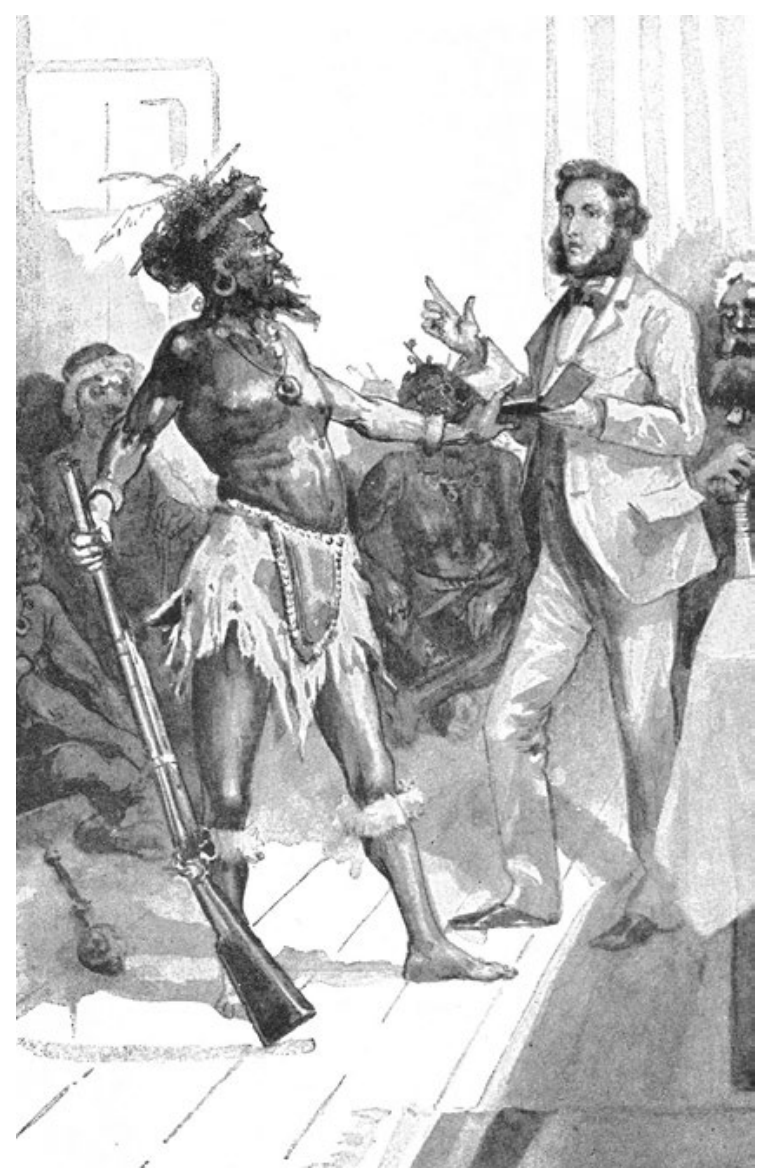

Figure 15. Bible vs rifle.

Source. John Paton, 1898, The Story of John G. Paton Told for Young Folks, or Thirty Years among South Sea Cannibals, London: Hodder and Stoughton, p. 81. 
TOURING PACIFIC CULTURES

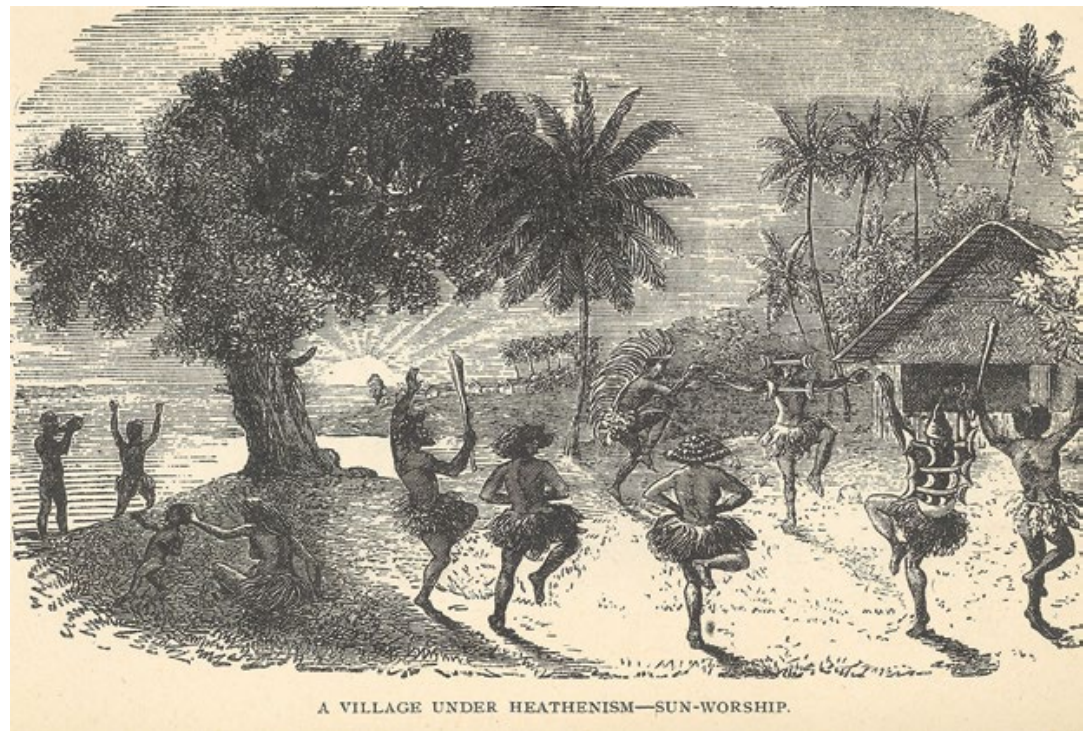

Figure 16. Heathen darkness, before.

Source. Emma H. Adams, 1890, Two Cannibal Archipelagoes: New Hebrides and Solomon Groups, Oakland, CA: Pacific Press Publishing, p. 90.

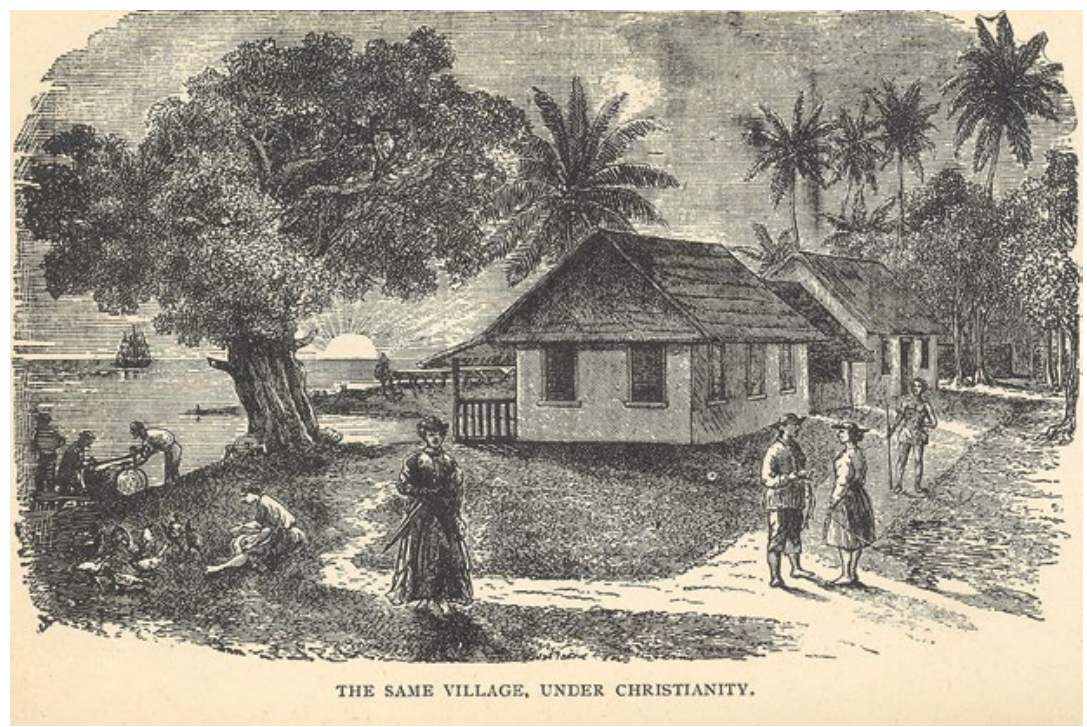

Figure 17. Christian light, after.

Source. Emma H. Adams, 1890, Two Cannibal Archipelagoes: New Hebrides and Solomon Groups, Oakland, CA: Pacific Press Publishing Co., p. 91. 


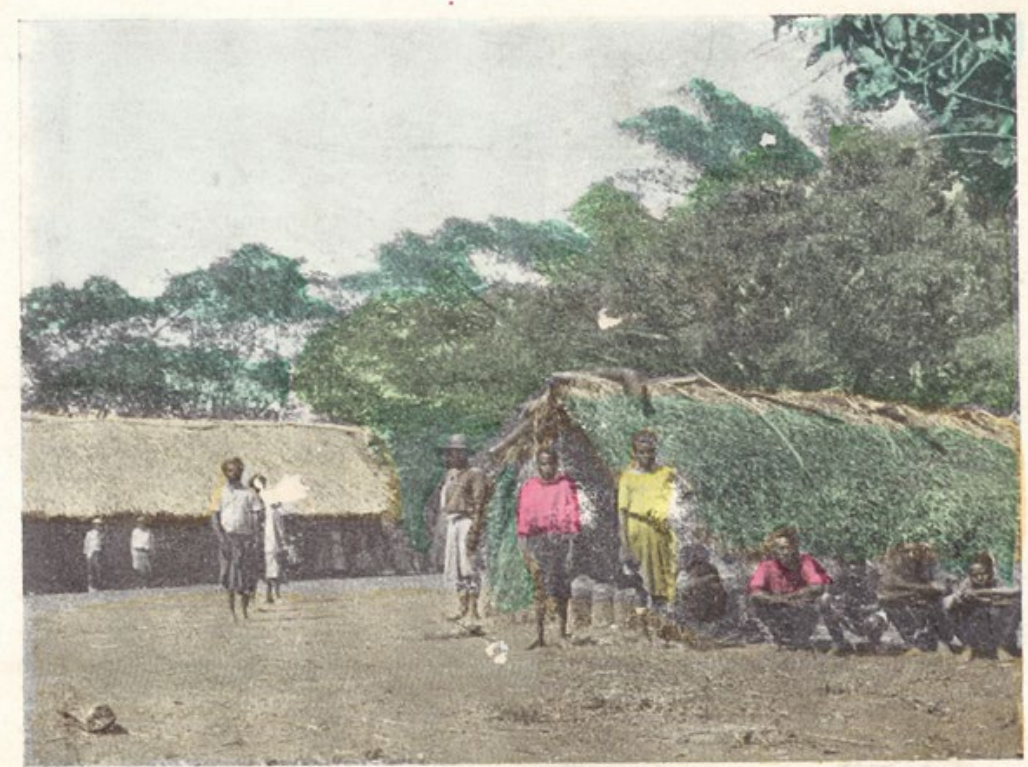

"Kava" House about to be destroyed, Village School on left.

Figure 18. School supplants kava houses.

Source. Anonymous; author's collection.

To portray possibility of Christian transformation, as Thomas has noted, ${ }^{35}$ mission representation of islanders tilted towards metaphors of age more than of gender. Islanders were children but nonetheless could develop and mature if bathed in Christian light. Colonial administrators and settlers, conversely, tended more often to feminise islanders. Portrayed and fixed thusly as female, witless and weak, islanders would require long and firm tutoring by their white masculine masters, an interminable colonial administration. Mission imagery, however, portrayed a happier future. One could, in fact, hope for Christian maturity and an ultimate shared humanity as sibling children of God. 


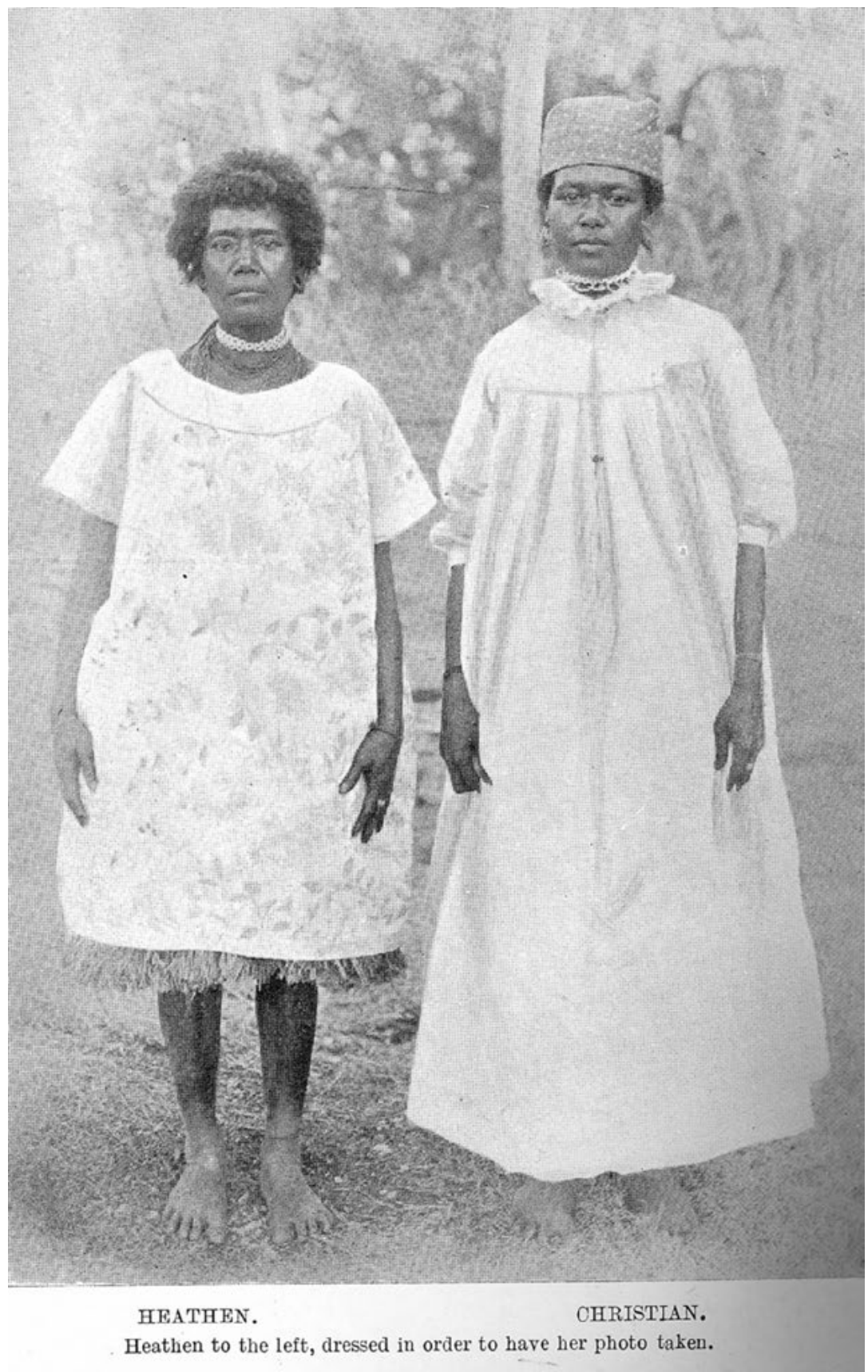

Figure 19. Heathen and Christian.

Source. William Gunn, 1924, Heralds of Dawn: Early Converts in the New Hebrides, London: Hodder and Stroughton, facing p. 127. 
Mission images thus often played with the passing of the old, with their heathen idols, and their replacement by vigorous and healthy Christian youth, as did the frontispiece of missionary Robert Lamb's autobiography (Figure 20): 'The old men ... sit down together and weep' ${ }^{36}$ Taking their place, a new generation of Christian youth will remake their island homes. Mission imagery frequently portrayed local children, scrubbed and dressed in preparation to join global Christian civilisation, as does a postcard (Figure 21) of babies newly washed in the blood of Jesus, and in water, too. If unlikely ever to become British knights, cleansed island children would at least be educated in proper spirituality in mission schools and as the offspring of caring, convert fathers and mothers. ${ }^{37}$ Christian families thus were another very common motif in missionary literature. Frank Paton, for example, included six family portraits in Lomai of Lenakel, including one of Titonga, Litsi, and their child Somo (Figure 22). ${ }^{38}$

Mission images, shaped to serve parochial goals, dominated representations of island life before mass tourism and before more diverse information sources developed. These pictures often were not always graphically reliable as many illustrators - who had never themselves met an actual islander-defaulted to drawing generic heathen or indeterminate native (see, for example, Figure 7). Generic imagery circulated from book to book - this also a form of travel as pictures were recycled and reused. The same illustration, for example (Figure 10), might appear in a series of mission journal articles and books, recaptioned for a variety of purposes. Emma Adams' 1890 tale of mission work in two 'cannibal archipelagoes', recycled the same depictions of transformed village life (Figures 16 and 17) that earlier had appeared in William Watt Gill's 1876 mission account: where they were captioned 'A village in Pukapuka, under heathenism' and 'The same village, under Christianity'. ${ }^{39}$ God, the Gospel, and natives taken everywhere to be about the same, readers may not much have minded illustrative leaps from the Cook Islands into Melanesia as pictures made their rounds.

\footnotetext{
36 Robert Lamb, 1905, Saints and Savages: The Story of Five Years in the New Hebrides, Edinburgh and London: William Blackwood and Sons.

37 Weir, "“Deeply interested in these children whom you have not seen"”, pp. 58-59.

38 Frank H.L. Paton, 1903, Lomai of Lenakel: A Hero of the New Hebrides. A Fresh Chapter in the Triumph of the Gospel, London: Hodder and Stoughton, facing p. 150.

39 William Watt Gill, 1876, Life in the Southern Islands; or, Scenes and Incidents in the South Pacific and New Guinea, London: Religious Tract Society, pp. 18-19.
} 


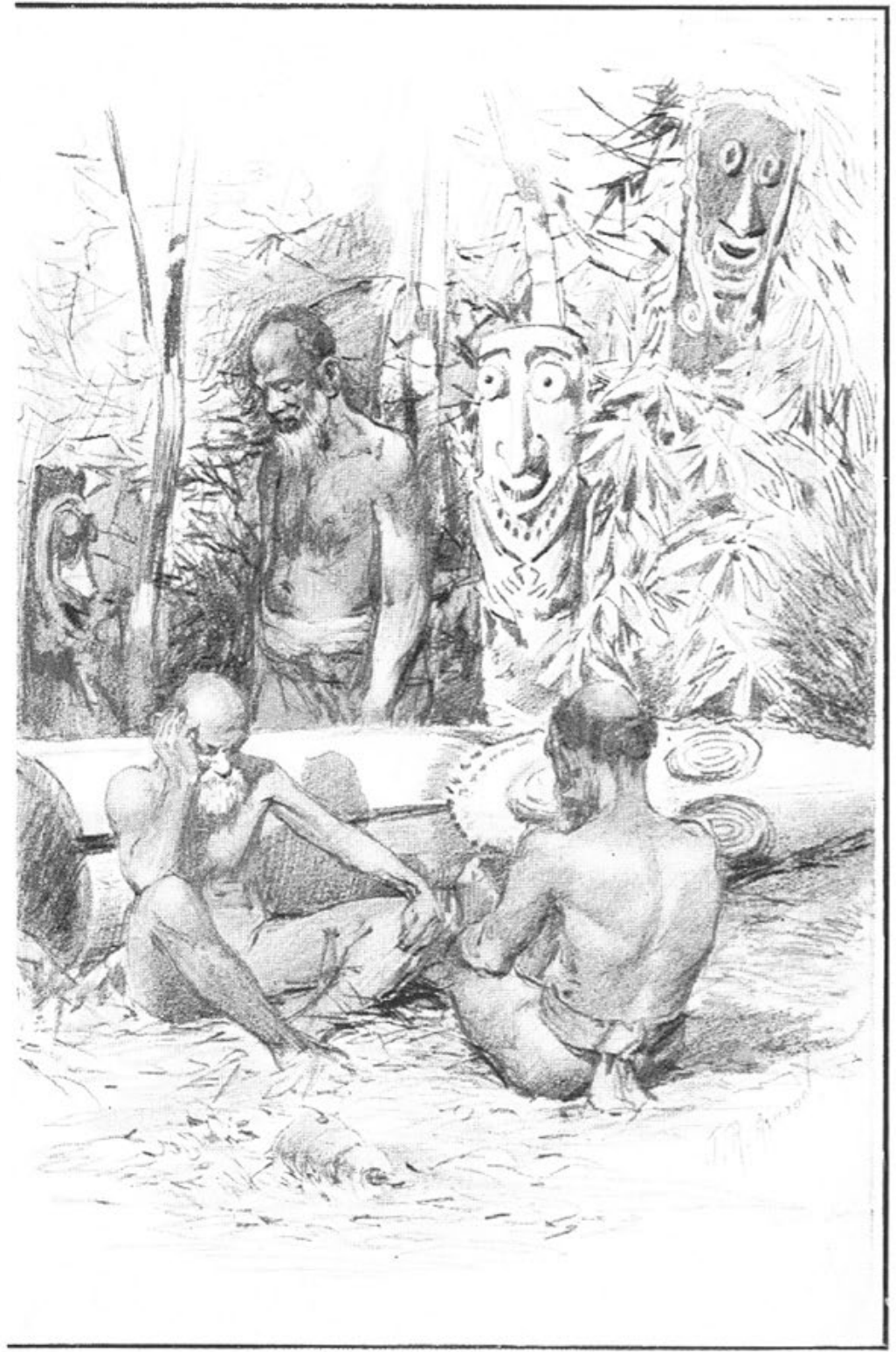

"AMONG THE BROKEN GODS."

“THE OLD MEN . . SIT DOWN TOGETHER AND WEEP."-PAGE 224.

Figure 20. Old men and their broken gods.

Source. Robert Lamb, 1905, Saints and Savages: The Story of Five Years in the New Hebrides, Edinburgh and London: William Blackwood and Sons, frontispiece. 


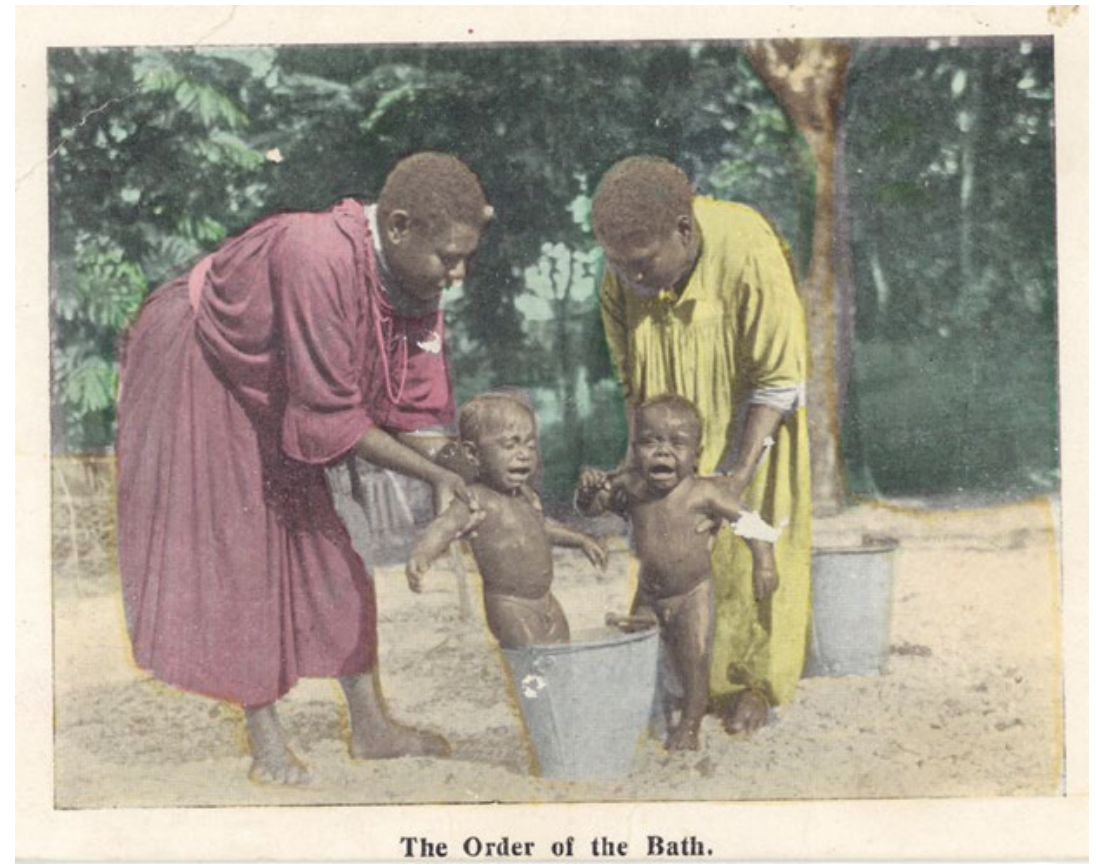

Figure 21. The order of the bath.

Source. Anonymous; author's collection.

Other mission images, however, particularly photographs and those drawings based on photographs (Figure 23), ${ }^{40}$ more accurately depicted island reality. These, although certainly posed, did capture some measure of ethnographic authenticity. Mission writers often also included drawings and photos of landscape to ground their texts. Maggie Paton's book, for example, featured her sketches of Tanna's Iasur volcano and an Erromango island beach scene, ${ }^{41}$ and Agnes Watt's letters were illustrated by photographs also of Tanna's volcano and its nearby lake along with a mountain waterfall. ${ }^{42}$

40 Patterson, Missionary Life among the Cannibals, p. 498.

41 Paton, Letters and Sketches from the New Hebrides, pp. 339, 343.

42 Watt, Twenty-five Years' Mission life on Tanna, New Hebrides, pp. 69, 175, 347. 
TOURING PACIFIC CULTURES

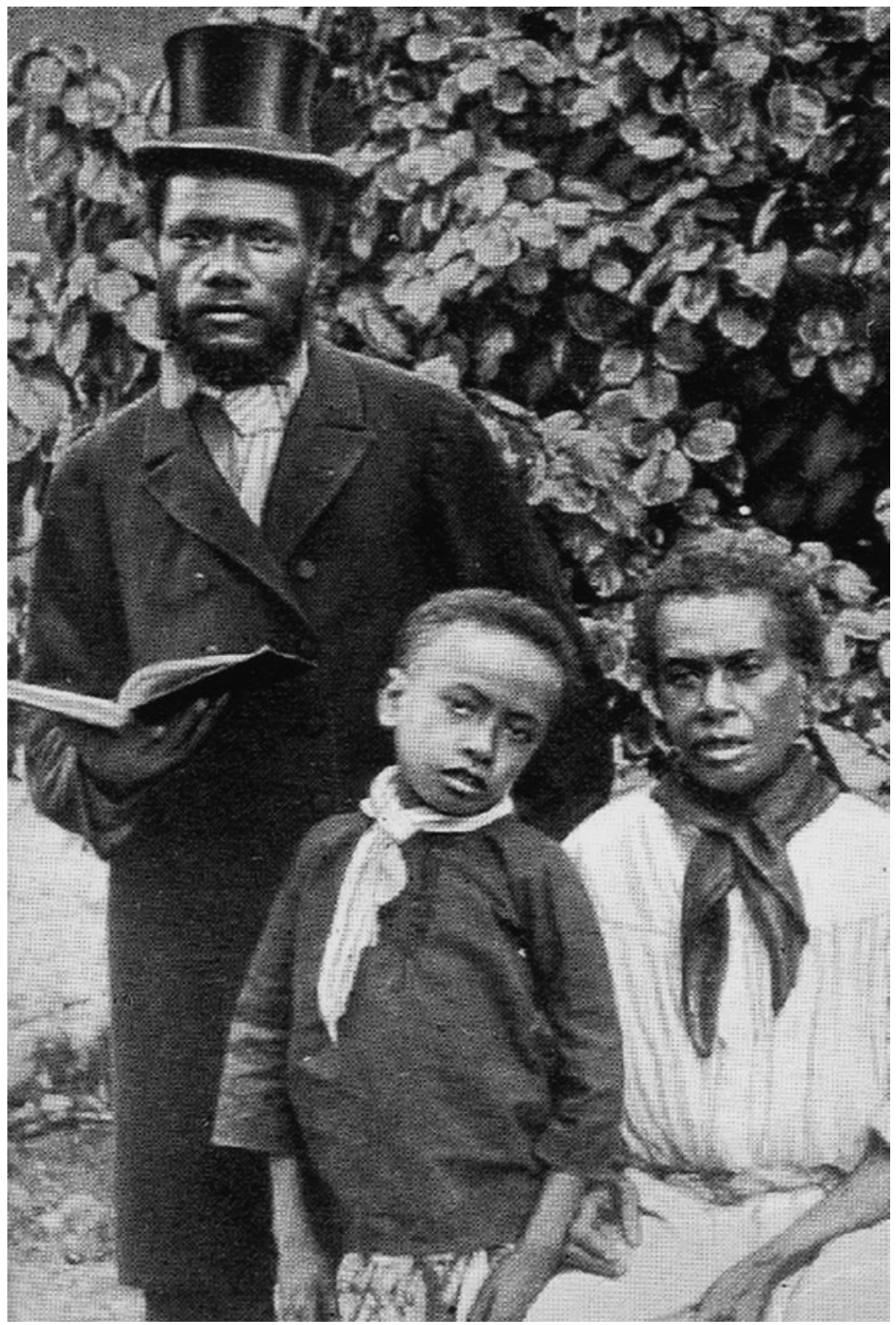

Figure 22. The new Christian family.

Source. Frank H.L. Paton, 1903, Lomai of Lenakel: A Hero of the New Hebrides. A Fresh Chapter in the Triumph of the Gospel, London: Hodder and Stoughton, p. 151. 


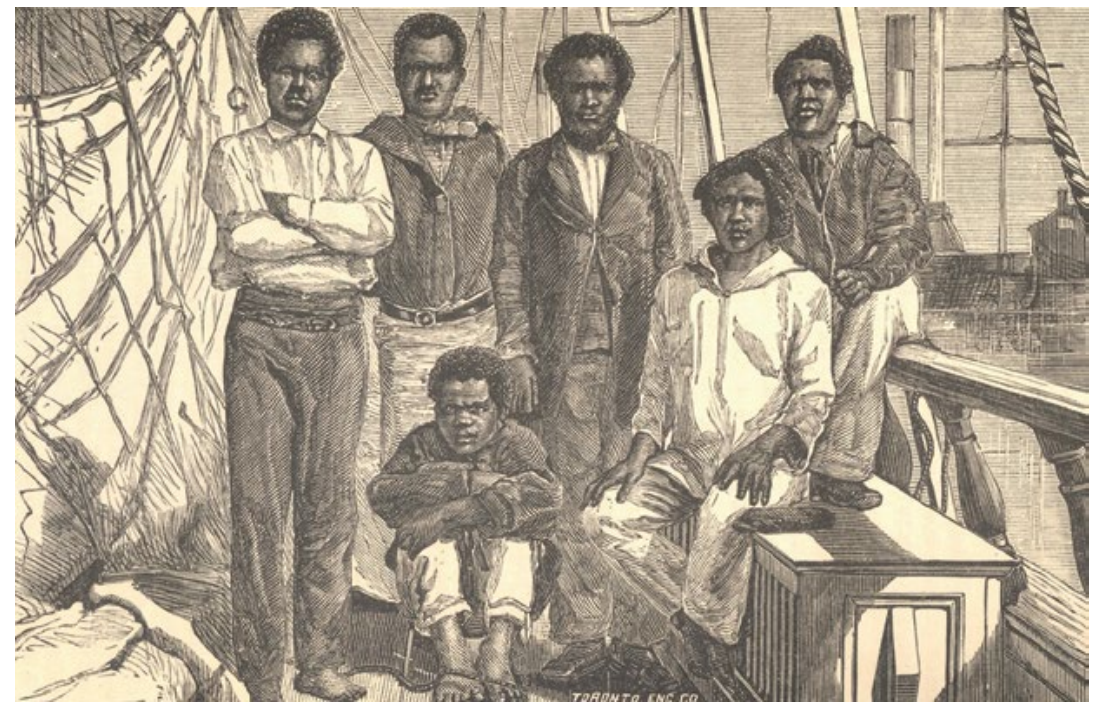

Figure 23. Dayspring's island crew.

Source. George Patterson, 1882, Missionary Life among the Cannibals: Being the life of the Rev. John Geddie, D.D., First Missionary to the New Hebrides, Toronto: James Cample \& Son, James Bain \& Son, and Hart \& Co, p. 498.

These mission landscapes and portraits in book, lantern slide, or postcard carried views of the islands forth into the outside world. Until the beginnings of mass tourism, print images moved more easily and freely than did people; the circulation of representative pictures as book illustration or postcard far eclipsed that of people themselves, although these too were on the move. Figure 23, for instance, which began as a photograph on board Dayspring, was transformed into an etching in Toronto, to be appreciated by Presbyterian faithful around the world. It depicts New Hebrideans who, along with their images, were then also travelling. Islanders like Dayspring's crew beginning in the 1860s journeyed abroad and sailed regularly into Sydney, Melbourne and Auckland, just as outsiders were increasingly arriving on island shores.

Although missionaries continue to arrive in Vanuatu today and metropolitan churches send hordes of youthful volunteers annually into these islands, mission views no longer dominate the global graphic archive. Still, these views for many years cultivated powerful expectations of island life, and the tropes that capture this, and they have sunk down deep into common knowledge of tropical people and places. The increasing numbers of tourists visiting Tanna today, 
for example, may not expect to have their bed linens stolen, but they do arrive with existing, directed if diffuse expectations of what they will find there..$^{43}$ Travelling mission images significantly framed and sparked much of the tourism to come.

\section{References}

Adams, Emma H. 1890. Two Cannibal Archipelagoes: New Hebrides and Solomon Groups. Oakland, CA: Pacific Press Publishing Co.

Adams, Ron. 1984. In the Land of Strangers: A Century of European Contact with Tanna, 1774-1874. Pacific Research Monograph. Canberra: Australian National University Press.

Ahrens, Prue, Lamont Lindstrom and Fiona Paisley. 2013. Across the World with the Johnsons: Film, Photography, and American Empire. Farnham: Ashgate.

Angleviel, Frédéric and Max Shekleton. 1997. “'Olfala pija blong Niuhebridis blong bifo": Old pictures of the early New Hebrides (Vanuatu).' Pacific Studies 20(4): 161-85.

Bryum, Bessie L. 1924. John G. Paton: Hero of the South Seas. Anderson, IN: Warner Press.

Connell, John and Prue Robinson. 2008. "Everything is truthful here": Custom village tourism in Tanna, Vanuatu.' In Tourism at the Grassroots: Villagers and Visitors in the Asia-Pacific, ed. John Connell and Barbara Rugendyke, pp. 77-97. London: Routledge.

Connell, John and Barbara Rugendyke (eds). 2008. Tourism at the Grassroots: Villagers and Visitors in the Asia-Pacific. London: Routledge.

\footnotetext{
43 See John Connell and Prue Robinson, 2008, “"Everything is truthful here": Custom village tourism in Tanna, Vanuatu', in Tourism at the Grassroots: Villagers and Visitors in the Asia-Pacific, ed. John Connell and Barbara Rugendyke, pp. 77-97, London: Routledge. See also John Taylor, 'Pikinini in paradise: Photography, souvenirs and the fantasy of 'child native' in tourism', this volume, for discussion of contemporary tourist appreciation of island children.
} 
Don, Alexander. 1918. Light in Dark Isles: A Jubilee Record and Study of the New Hebrides Mission of the Presbyterian Church of New Zealand. Dunedin: Foreign Missions Committee, Presbyterian Church of New Zealand.

Douglas, Ngaire. 1996. They Came for Savages: 100 Years of Tourism in Melanesia. Alstonville, NSW: Southern Cross University Press.

Ferguson, John Alexander. 1917-1943. A Bibliography of the New Hebrides and a History of the Mission Press, parts 1-3. Sydney: privately printed.

Frater, Maurice. 1922. Midst Volcanic Fires: An Account of Missionary Tours among the Volcanic Islands of the New Hebrides. London: James Clarke.

Gill, William Watt. 1876. Life in the Southern Islands; or, Scenes and Incidents in the South Pacific and New Guinea. London: Religious Tract Society.

Gunn, William. 1924. Heralds of Dawn: Early Converts in the New Hebrides. London: Hodder and Stroughton.

Kaplan, Daile. 1984. 'Enlightened women in darkened lands.' Studies in Visual Communication 10: 61-77.

Lamb, Robert. 1905. Saints and Savages: The Story of Five Years in the New Hebrides. Edinburgh and London: William Blackwood and Sons.

Landau, Paul. 1994. 'The illumination of Christ in the Kalahari Desert.' Representations 45: 26-40.

Langridge, A.K. and F.H.L. Paton. 1910. John G. Paton: Later Years and Farewell. London: Hodder and Stoughton.

Laracy, Eugénie and Hugh Laracy. 1977. ‘Beatrice Grimshaw: Pride and prejudice in Papua.' Journal of Pacific History 12: 154-75.

Lübcke, Antje. 2012. 'Two New Hebrides Mission photograph albums: An object-story of story-objects.' Journal of Pacific History 47: 187-209. 
Melanesian Mission. 1913. 'What helps to make successful meetings: Hints to Local secretaries.' The Southern Cross Log (December): 197-99.

Michael, Charles D. 1912. John Gibson Paton, DD: The Missionary Hero of the New Hebrides. London: S.W. Partridge \& Co.

Michelsen, Oscar. 1893. Cannibals Won for Christ: A Story of Missionary Perils and Triumphs in Tongoa, New Hebrides. London: Morgan and Scott.

Paton, Frank H.L. 1903. Lomai of Lenakel: A Hero of the New Hebrides. A Fresh Chapter in the Triumph of the Gospel. London: Hodder and Stoughton.

Paton, John G. 1890. An Autobiography. London: Hodder and Stoughton.

Paton, John. 1898. The Story of John G. Paton Told for Young Folks, or Thirty Years among South Sea Cannibals. London: Hodder and Stoughton.

- 1923. The Story of John G. Paton's Thirty Years with South Sea Cannibals, ed. Dr. James Paton, revised by A.K. Langridge. London: Hodder and Stoughton.

Paton, Maggie Whitecross. 1894. Letters and Sketches from the New Hebrides. London: Hodder and Stoughton.

Patterson, George. 1864. Memoirs of the Rev. S.F. Johnston, the Rev. J.W. Matheson, and Mrs. Mary Johnston Matheson, Missionaries on Tanna. Philadelphia: W.S. \& A. Martien.

- 1882. Missionary Life among the Cannibals: Being the life of the Rev. John Geddie, D.D., First Missionary to the New Hebrides. Toronto: James Cample \& Son, James Bain \& Son, and Hart \& Co.

Robertson, H.A. 1903. Erromanga: The Martyr Isle. London: Hodder and Stroughton.

Shepard, Elizabeth. 1987. 'The magic lantern slide in entertainment and education, 1860-1920.' History of Photography 11: 91-108. 
Taylor, John. n.d. 'Pikinini in paradise: Photography, souvenirs and the fantasy of 'child native' in tourism.' Unpublished paper.

Thomas, Nicholas. 1992. 'Colonial conversations: Difference, hierarchy, and history in early twentieth-century evangelical propaganda.' Comparative Studies in Society and History 34: 366-89.

Watt, Agnes Craig Patterson. 1896. Twenty-five Years' Mission life on Tanna, New Hebrides. Paisley: J. and R. Parlane.

Weir, Christine. 2013. "Deeply interested in these children whom you have not seen": The Protestant Sunday School view of the Pacific.' Journal of Pacific History 48: 43-62. 
This text is taken from Touring Pacific Cultures, edited by Kalissa Alexeyeff and John Taylor, published 2016 by ANU Press, The Australian National University, Canberra, Australia. 